\title{
Preserving and Extending the Commodification of Football Supporter Relations: a Cultural Economy of Supporters Direct
}

\author{
by David Kennedy and Peter Kennedy \\ Glasgow Caledonian University; Glasgow Caledonian University
}

\author{
Sociological Research Online, Volume 12, Issue 1, \\ $<$ http://unw.socresonline.org.uk/12/1/kennedy.html> \\ doi:10.5153/sro. 1479
}

Received: 3 May 2006 Accepted: 12 Dec 2006 Published: 31 Jan 2007

\begin{abstract}
This paper examines the role of Supporters Direct, a sports policy initiative launched by the British Labour government in 2000. The objective of Supporters Direct is to democratise football clubs by intervening in what it views as the unequal relationship that exists between the relatively powerless supporters of football clubs and private shareholders who have organisational control of clubs. They hope to achieve this by facilitating mutual forms of ownership and control of clubs via supporters' trusts. With respect to this objective, established research concerning Supporters Direct emphasises this initiative as an inherently progressive development for the football industry. The aim of this paper is to situate the development of Supporters Direct in the wider context of the British Labour Government's policy of social inclusion. On the basis of a textual analysis that draws on current literature in the area of culture and economy - with specific reference to processes of commodification - we reveal an alternative view of Supporters Direct. The Supporters Direct initiative, we conclude, is an integral part of a social policy aimed at the preservation and extension of commodified social relations.
\end{abstract}

\section{Keywords: Supporters Direct; Supporters' Trusts, Social Inclusion, Mutualism, Commodification}

\section{Introduction}

1.1 The objective of this paper is to offer analysis of Supporters Direct, an initiative launched in 2000 by the New Labour Government aimed at the restructuring of ownership and control of British football clubs. Supporters Direct, an organisation funded by Sport England and Sport Scotland - bodies accountable to the Department of Culture, Media and Sport, and the Scottish Executive's Department of Tourism, Culture and Sport, respectively - are primarily concerned with aiding the formation of supporters' trusts at football clubs $^{[1]}$ run along mutual, not-for-profit lines. The ultimate goal of Supporters Direct is to bring about democratic, supporter ownership of football clubs (Supporters Direct, 2006a).

1.2 Existing research carried out on Supporters Direct has served to confirm and underline the potential of Supporters Direct as a suitable vehicle to exact the corporate reform of professional football clubs in the direction of mutual ownership and away from the often short-term interests of private shareholders. Essentially, the established view of the Supporters Direct initiative - and the notion of the desirability for football clubs to be run along mutual lines - is that such developments offer a viable "Third Way" for the future of the game in Britain. Put simply, the Third Way strategy is an overarching New Labour social philosophy designed to overcome sectional differences that occur in all areas of society. Its objective is to encourage a broad set of opinions to be heard and to have influence over the policy decision-making process - to allow "communities" of different interests to bring about solutions to conflict through consensus. In the context of football this has meant New Labour's support for initiatives which encourage the social inclusion of all elements of a football community - directors, shareholders, non-stock holding supporters, as well as local authorities and local voluntary groups - in the decision-making process of a football club. In the academic community this social objective is most obviously identified with the members of the Football Governance Research Centre at Birkbeck College, University of London who have become closely identified with Supporters Direct and the championing of mutual forms of ownership and control of football clubs. ${ }^{[2]}$ Their view is that only by a radical overhauling of the way in which football clubs are currently owned and controlled can the game continue to enjoy the prominence and social role it has historically enjoyed in Britain. Current research is founded on the assumption that the formation of 
Supporters Direct is an inherently progressive development in this respect. The aim of this paper is to question that established viewpoint by situating the development of Supporters Direct in the wider context of New Labour's policy of social inclusion.

1.3 The paper is structured into three main sections. In section one, the origins of Supporters Direct are located. Here we outline the state of professional football in Britain when New Labour took office in 1997. The condition of the British game had an influential role in determining the incoming Labour Government's policy to tackle the problem of social exclusion, which had been allowed to build up in many local communities and which they inherited from the previous Conservative Government's reign in office. In this first section we outline the incoming government's attempt to address the manifestation of social exclusion in the culture of professional football. In section two, we build on this by contextualising Supporters Direct as a component part of New Labour's social inclusion policy - a policy whose ultimate aim, we argue, is the preservation and extension of commodified social relations. Finally, in section three, we highlight the ambiguity of Supporters Direct's position in relation to the process of commodification. Here, we focus on the complexities of the relationship between Supporters Direct and the supporters' trusts movement, and between supporters' trusts and grassroots football supporters.

\section{Section One}

\section{The Taylor Report}

2.1 The origins of Supporters Direct are to be found in the Football Task Force, a body set up in July 1997 by the newly elected Labour Government charged with overseeing an investigation into the state of the British game. The remit of the Task Force - comprising members of the Football Supporters Association, Football Association, Football League, and Premier League - was to suggest various ways in which government could facilitate wider participation in the game (playing and spectating), and to consider how conflict within the professional game between different interest groups - more especially over matters of ownership and control - could be resolved. ${ }^{[3]}$

2.2 The setting up of the Task Force can be said to have been the outcome of a turbulent preceding three decade period for British football, culminating in the stadium disasters at Heysel in 1985, and at Valley Parade and Hillsborough in 1989. British football was forced to "clean up its act" during the 1990s with respect to reducing the significant levels of hooliganism which had plagued the game since the early 1970s, and eliminating insalubrious, and sometimes dangerous, stadia conditions. The Taylor Report (1990) into the Hillsborough disaster, with its emphasis on the necessity for the creation of a new generation of football stadiums and for clubs to take a greater interest in the welfare of their supporters, provided the clarion call for the reinvigoration of the British game. The upturn in the game's fortunes post-Taylor report was manifest in improving attendance levels amongst football clubs, as capital investment for stadium builds and renovation work was made available to clubs from the Football Trust. ${ }^{[4]}$

2.3 However, other developments occurring in conjunction with these advances led to what many believe to have been a damaging restructuring of the British game. The desire on the part of the game's bigger clubs to secure a greater proportion of the growing television revenue attracted into football - more especially via satellite television companies - led to the decision by elite English clubs to form a Premier League, starting from the $1992 / 93$ season, ${ }^{[5]}$ to be governed by the Football Association. This meant their breaking away from the jurisdiction of the Football League, a body committed to negotiate for the best commercial deal it could for all 92 of its affiliated League clubs. ${ }^{[6]}$ The outcome of this move was that, during the course of the 1990s, a dramatic imbalance developed between the income of elite clubs and that of lower league clubs, threatening the survival of clubs outside of the Premiership: 'The gap between Premier League and Football League', commented football industry auditors Deloitte and Touche in 1998, had turned 'from gap, to chasm to abyss'. ${ }^{[7]}$

2.4 In addition to this growing financial division between elite and lower divisions, many clubs took the opportunity during the 1990s to float on the Stock Exchange. For institutional shareholders the elite clubs proved especially attractive, with their lucrative television contracts and the potential they held for profitable gain from merchandising. More generally, at both PLC and privately owned football club companies, increased ticket prices way above rises in inflation placed a formidable obstacle in the path of traditional supporters wishing to attend football matches. Due to this pricing policy it has been argued that there has occurred a 'gentrification' of football, as supporters from more affluent backgrounds increased their attendance levels at the expense of the lower paid. This has been especially the case at English Premiership clubs, ${ }^{[8]}$ where season ticket prices have vastly outstripped the level of inflation since the early 1990s (though at lower league clubs the rising cost of match day attendance is also likely to have priced out much of the "traditional" fanbase ${ }^{[9]}$ ). The result of the changing demographic of football has resulted in 
some instances in a disengagement by clubs in terms of attracting support from communities experiencing high levels of multi-deprivation in favour of encouraging support from 'relatively affluent' areas enjoying 'high employment rates and good levels of education and health' (Brown et al, 2006: 52).

\section{The 'One Game' Principle and the Creation of the Football Task Force}

2.5 The increasing level of commercialisation of the British game during the 1990s is said to have run counter to the traditions of British football's historical development (Hamil et al, 2000; Burnham, 2003: 1415). Professional football had been, indisputably, the national sport for over a century, watched weekly by hundreds of thousands of fans throughout Britain, and playing a vital part in sustaining the fabric of civil society. It has been pointed out that, historically, the football authorities in Britain had 'recognised the twin dangers to football from unregulated market forces and private ownership of clubs' and took decisive action to avoid the very situation that has arisen latterly whereby profit-seekers have entered into the ownership of clubs (Burnham, 2003, 14). Principally this was done by avoiding the payment of directors of clubs, preventing the sale of club assets, and by setting in place 'a strong system of income-sharing to maintain competitive balance' (Burnham, 2003: 14-15).

2.6 There is debate over the primary motivation of professional football clubs taking the incorporation route. Steven Tischler (1981: 69-87), in particular, has made the case for seeing this transition in terms of the expansion of capitalist exploitative relations into what was, for the most part, a working class cultural pursuit. ${ }^{[10]}$ However, there seems to be a consensus within football historiography that the shift from club to club-company status had a more benign motive: incorporation as a means to raise capital to invest in a club as a competitive sporting organization, rather than to make profits for shareholders (Mason, 1980; Holt, 1989; Russell, 1996). ${ }^{[11]}$ For the most part, football clubs retained their status as the members' organisations they had started out as. The not-for-profit, "one game" principle held sway for a century prior to its dismantling and the opening up of football to market forces as another 'branch of the entertainment industry' ${ }^{[12]}$ (Football Association, 1991: 145).

2.7 The path that football had taken latterly, though, brought with it what were viewed as unacceptable socio-economic consequences, not only for football fandom, but also for the communities, which had traditionally supported professional clubs (Wagg, 1998). It was into this environment that the Football Task Force was launched. The Task Force's attempt to tackle the increasing trend toward commercialisation in football brought about a series of reports, and some of their recommendations were implemented. ${ }^{[13]}$ However, the proposal by a majority on the Task Force (outlined in the Task Force final report at the end of 1999) to set up new institutions of governance of the game met stiff resistance from the minority of delegates within that body representing the football authorities. These delegates were opposed to any radical overhaul of the game's power structures. The majority of members on the Task Force advocated: the setting up of a Football Audit Commission, a wholly independent of the game's authorities and capable of enforcing sanctions in the case of exploitative merchandising (Faulkner, 2000); a Football Compliance Unit, which would investigate any financial irregularities occurring within clubs; an 'Ombudsfan' to act in the interests of ordinary football supporters; and the need for the development of new models of football club ownership and, in particular, to actively encourage supporters to purchase club shares with the long-term aim of supporter ownership (The Football Task Force, 1999). However, representatives of the Football Association, the Football League, and the Football Premiership in the Task Force rejected these proposals, arguing that the existing self-governing structures of professional football were flexible and adaptive enough to carry through financial reforms, and to develop supporter involvement through supporter forums to the benefit of all stakeholders.

2.8 The bolder call for new regulatory bodies with statutory powers was rejected by the then Minister for Sport, Kate Hoey. Rather than set up new forms of corporate governance, the preferred government option was to support the status quo and the continuance of self-regulation on the part of the football authorities. The Labour Government, as one member of the Task Force put it, 'steadfastly refused to intervene against the interests of business' (Brown, 2002). The Task Force majority's view did hold sway, though, in the government's advocacy of the principle that supporters take greater participation in, and ownership of, football clubs. Chris Smith, Minister of State for Culture, Media and Sport, announced the formation of Supporters Direct, the result of a compromise between the two Task Force factions, in October of 1999.

2.9 This, then, was the fruition of New Labour's attempt to readjust the balance of forces within the game in the wake of the commercialisation process it went through during the 1990s, a period when football (hitherto an institution whose importance lay with its social meaning and social usefulness) was being transformed, more and more, into a vehicle for saleable goods and services (Hamil et al, 2000: 29-30). With little government appetite to impose a radical, "top down" regulation of football club governance, a hoped for grassroots solution to the sport's ills was put into operation. The "bottom up" regulation that the formation of 
Supporters Direct represented had the task of 'nothing less than the democratization of football clubs' (Hamil et al, 2000: p.xi).

\section{Supporters Direct}

2.10 The primary aim of Supporters Direct is to 'Promote and support the concept of democratic supporter ownership and representation' in football clubs (Supporters Direct, 2006a). To facilitate this objective Supporters Direct - through legal advice and funding - help to form supporters' trusts at clubs; encourage the democratic representation of supporters' trusts on football club boards; and promote the idea of ownership of shares in clubs by supporters' trusts (Supporters Direct, 2006a). The advocated model of 'football community mutual' for supporters' trusts is based on the industrial and provident societies (I\&PS). ${ }^{[14]}$ Under the I\&PS model, ownership of shares in a football club are held in common with other trust members, and these shares carry with them no rights for individuals involved in the trust to gain dividends. Dividend payments are ploughed back into the club through the purchase of more shares for the trust. In the event of a trust being wound up, any surplus left after paying debts goes to local charities or other not-for-profit organisations. ${ }^{[15]}$ 'All of this means that a football mutual cannot be used as a vehicle for making profit and that its assets (which could include shares in a football club) cannot be cashed in by unscrupulous members in the future' (Jaquiss, 2000).

2.11 Since its launch in August 2000, Supporters Direct has enjoyed great success in expanding the number of supporter's trusts amongst British football clubs. Supporters' trusts are now commonplace in clubs playing in the major leagues of England and Scotland. In England, out of the 92 clubs that comprise the Premiership, Championship, Football League One and Football League Two, 59 clubs have supporters' trusts; out of the 42 Scottish clubs in the Scottish Premier League, Scottish Football League One, Scottish Football League Two, and Scottish Football League Three, 31 clubs have supporters' trusts (Supporters Direct, 2006b: 32). In total, 127 football supporters' trusts have been established under the auspices of Supporters Direct, having a combined membership of over 95,000. At the time of writing, 61 supporters' trusts hold equity within their clubs and 39 trusts have a member of their organisation on the board of directors of their clubs (Supporters Direct, 2006a).

2.12 There is a great air of confidence about the possibilities opened up by the creation of supporters' trusts from within the hierarchy of Supporters Direct (Boyle, 2003: 18, 23). Moreover, this confidence seems to be shared by the game's authorities: Supporters Direct is seen by football's European governing body, UEFA, to be a suitable role model for clubs in other member countries to follow in terms of the ownership, control and management of football clubs (Arnaut, 2006: 71-72).

2.13 It has also established itself on the political landscape. The New Labour Government view the Supporters Direct initiative as integral to their agenda to intervene into the social existence of community life in British towns and cities where supporters' trusts are encouraged as a means to combat the social exclusion of marginalized groups within urban communities. As Kevin Rye, Supporters Direct's Development Officer, states 'the government values [Supporters Direct's] contribution to the game, and also acknowledges that football has a massive part to play in the health and social inclusivity agendas of, particularly, young people' (Supporters Direct, 2004: 4). Confirming this view, Labour Chancellor, Gordon Brown, speaking at the Fourth Annual Supporters Direct Conference in October 2004, underlines the importance of Supporters Direct as 'a beacon of success for others to follow' (Supporters Direct, 2006b: 10). Underlining the intimacy of Supporters Direct and New Labour is the fact that senior figures in Supporters Direct, such as Andy Burnham MP, the former chairman of Supporters Direct, and Philip French, the current Chief Executive, have strong associations with the New Labour government: Burnham is a Home Office minister; French, a past adviser to Secretary of State, Tessa Jowell, at the Department of Culture, Media and Sport.

2.14 Horne (2006) notes in particular how developments in sport and sports policy are to be understood in the context of neo-liberalism, the pursuance of a political philosophy of individualism and a political economy of market liberalisation which extends both the state and the market into civil society shrinking the autonomy of the voluntary sector, as it is increasingly subjected to state policy in the form of 'cultural governance' and its basic relations become 'market-driven' (Horne, 2006: 96). In the UK, first Thatcherism and then the Third Way policies of Blair have extended neo-liberalism (Horne, 2006: 98), celebrating the 'efficiencies' of market-driven relations and the unavoidability of structural inequalities (Horne, 2006: 99). In this context, sport, and football policy in particular, aspire to promote social inclusion through the discourse of an 'enterprise culture', in which individuals and institutions within civil society are encouraged to become self-reliant and make responsible choices as autonomous citizen-consumers (Horne, 2006: 103), rather than social activists. In to this 'sporting landscape', government policy interventions, such as the creation of Supporters Direct, restrict the role of football supporters to one of 'consumer-stakeholder' (Horne, 2006: 110). 


\section{Summary}

2.15 To recap, the present Labour Government has taken a keen and active interest in developments in professional football since it was first elected in 1997. The reason for their intervention seems clear enough: professional football is the number one national sport watched weekly by hundreds of thousands of fans throughout Britain and plays a vital part in sustaining the fabric of civil society. Yet this potential has, relatively recently, been weakened by forces of commercialisation. The increased emphasis on commercial success in the sport has placed the existence of most professional clubs below the elite clubs in some jeopardy, and strains to breaking point the loyalty of supporters at all levels of the game through hikes in ticket pricing and excessive merchandising. Supporters Direct is the creation of government, who directly finance it. While this does not rule out its own independence as a think tank and the potential to act as a practical force for positive change in the governance of professional football, the context in which Supporters Direct finds itself does bring it within the ideological influence of government policy and, in particular, that of its wider agenda of social inclusion. ${ }^{[16]}$

2.16 Under New Labour, the policy of social inclusion has become fundamental to its governance of the state, forming an interconnected hub around which a number of related policy programmes revolve in attempting to extend governance into civil society. In the following section of the paper we turn our attention toward a critique of its intervention into professional football and its influence on the role of Supporters Direct in particular.

\section{Section Two}

\section{'Third Way' and the Relationship Between Culture and Economy}

3.1 As outlined above, Supporters Direct is part of the government's wider social inclusion initiative, which is intimately related to Labour's Third Way. The Third Way is a critique of neo-liberalism, which accepts that markets and the profit motive are economically efficient, but embraces the argument that markets must be regulated as part of a wider commitment to addressing the social injustices, inequalities and isolation that followed in the wake of the previous Conservative Government's endorsement of a free market philosophy. According to the Third Way, government's ought to foster the advantages of the market through publicprivate-partnerships in order to secure economic efficiency and sustainable economic growth while, at a cultural level, introducing social reforms that foster social inclusion, individual and community responsibility and an ethic of civic duty. To this extent, the Labour government is inspired by the belief that social and public policy can regulate for a socially inclusive market society that brings forth all the benefits of the free market without the attendant social problems that traditionally accompany this system.

3.2 For example, in the case of private-public partnerships in the area of sport and leisure, Reid illustrates how the development of sport and leisure trusts are linked to the social inclusion agenda through their claimed ability to impart a cultural change in the way they approach their objectives, including an increased sense of ownership and customer orientation (2003). Moreover, trusts are a means of fostering active citizenship, which is a central aspect of New Labour's social inclusion agenda, by drawing together people from different backgrounds into public service. In particular, it is the Labour government's claims to provide a Third Way in terms of attempting to regulate the articulation of culture and economy that provides the framework for understanding the relationship between its inclusion agenda and the influence it has over the development of Supporters Direct and supporters' trusts. It is, therefore, to a discussion of the relationship between culture and economy that we now turn.

3.3 According to Warde (2002) there are 'two alternative causal claims' concerning trends in the relationship between culture and economy. The first suggests that the dominant trend is towards the culturalisation of the economy (that aesthetic orientations and symbolic meanings are increasingly integral to the 'economic' object). The second suggests that culture is becoming increasingly commodified (that instrumental rational, calculative motivations are invading cultural practices). How we position ourselves in relation to these claims will very much depend on how we define 'culture' and also on which cultural objects we choose to focus our investigations on. Warde (2002) (following Williams, R., 1976) identifies three modern definitions of 'culture': intellectual, spiritual and aesthetic development; a particular way of life; and, intellectual and artistic creativity (2002: 187). On all three definitions, with the exception of 'the output of the culture industries', he remains unconvinced that culture has colonised economy, arguing that the commodification of everyday life remains the dominant tendency. However, Warde also acknowledges that, with respect to the consumption of specifically cultural objects, things may be different. In as much as cultural objects have been increasingly drawn into the market as consumables, then the demand for, and profitability of, these cultural objects as capital depends increasingly on their aesthetic and culturally symbolic qualities. 
3.4 This latter observation has implications for football. The expansion of commercialisation and the attendant marketing and merchandising of all aspects of the game depends less on economic calculus of costs to value and far more on the symbolic and iconic meanings attached to 'the consumption of football'. Therefore, at least in relation to cultural industries such as football, one may argue that the 'cultural' and the 'economic' are mutually constitutive of each other. In other words, the expansion of market relations and capital accumulation into the football industry, depend simultaneously on the attendant dispositions of formal rational action and calculable conduct and the symbolic and iconic meanings attached to 'the consumption of football'. However, this relationship should not simply be taken as read - as something axiomatic of the current state of capitalism. Instead, the relationship will unfold differently depending on the context and the object under construction - something only case by case investigation will reveal. For, as du Gay argues, both 'cultural' and 'economic' moments are 'techniques of economic management' that have to be continually invented and reinvented, 'stabilised and refined and reproduced'; and 'disseminated and implanted in practices of various kinds' (du Gay, 2002: 2). Viewed as 'techniques of economic management' the relationship between culture and economy - in as much as they harbour a dialectic between processes of commodification and culturalisation - illuminate New Labour's Third Way social inclusion agenda in general, and have a particular influence upon the current orientation of Supporters Direct.

3.5 The Labour Government's preoccupation with policy to enhance what it considers to be a more socially inclusive market society is testimony to both the culturalisation and commodification processes. Labour has continually emphasised its commitment to culturalisation of market relations in the shape and form of its keenness to promote the role of 'community' and 'partnership', both of which are fundamental to the wider social inclusion agenda. Likewise, Labour has continually emphasised that strong and vibrant 'communities' and 'public partnerships' depend on the development and expansion of market relations and market 'solutions'. In this respect, The New Deal and Welfare to Work Programmes, delivered through 'partnership' and 'community regeneration', are evidence both of Labour's attraction to the positive gains of commodifying the relationship between citizen and state, and their belief in the cultural benefits to be had from the synthesis of a public and private ethos (Levitas, 1998).

\section{Social Inclusion and Supporters Direct}

3.6 As noted earlier in this paper, the government have been keen to advocate the principle of football supporters having greater participation in, and ownership of, football clubs, as a means of readjusting the balance of forces in the wake of the game's increasing commercialisation. It was noted earlier in this paper how the commercialisation of football is in danger of altering the balance between culture and economy. Football as a cultural object defines its own unique balance between cultural meaning and economic project. In this respect, the regulatory impulse of the Football Task Force in setting up Supporters Direct expresses both the government's desire to limit the negative effects of commodification on the game as a whole, whilst registering their commitment to bolstering the aesthetic and symbolic aspects of the game (which attracts supporters in the first place, but which had become increasingly overrun by the economic rationality underpinning commodification). Both the Task Force and Supporters Direct are therefore expressions of the Labour Government's wider social inclusion agenda, born of an engagement with the wider context of the ongoing and shifting dynamic between forces of culturalisation and commodification.

3.7 However, as was also noted earlier, the Task Force 'steadfastly refused to intervene against the interests of business by supporting the much bolder vision of new regulatory bodies with statutory powers (Brown, 2002). A fact which indicates that, in attempting to strike the balance between culture and economy, or culturisation and commodification, the government has erred in favour of the latter, in much the same way that its' wider social inclusion agenda errs in favour of the benefits of market relations in overcoming exclusion from society. One could justifiably argue, in this respect, that the ultimate aim of the government's involvement in regulating football through Supporters Direct, is to extend the commodification of the game in ways that encourage a specific section of supporters to become involved in club ownership. This is most obviously seen at clubs where closure, or the semi-permanent state of receivership, is threatened as a result of the drying up of capital investment.

3.8 In the context of football, commodification transforms what is a cultural object par-excellence - with its own determinate social practices and complex, context specific, symbolic meanings - into its opposite: something general, calculable, economic and exchangeable. Relationships become more narrowly defined in terms of producer and consumer, leading to a more one-sided orientation to football. Instead of being engaged in all aspects of football as a use-value and social practice, individuals increasingly tend to take up positions as either producers/owners or customers/consumers. Ultimately, what gets forgotten in this process of commodification is the intrinsic reason for engaging with the object in the first place, as football effectively becomes an instrument in the much larger government objective of creating a socially inclusive, market society based around the extension of commodified relations. 
3.9 Yet Brick (2001) reminds us that the processes involved in commodification should not be thought of as being passively consumed by football fandom as docile bodies. Brick argues that supporters are active in shaping and contextualising the football experience, and that the commodification process can itself produce positive consequences for supporters (2001: 9). As an example of this, Brick points out that the increasing trend toward the commercialisation of football has allowed its spectacle to be 'consumed' more flexibly in accordance with flexible work regimes, and in spaces and places other than the stadia - for example, in social gatherings in pubs and clubs broadcasting live matches. Indeed, Brick suggests that, relative to the strict controls within the stadia, collective consumption 'offsite' offers an opportunity for supporters to express themselves on their own terms. (Brick, 2001:8)

3.10 Indeed the element of resistance to commodification and the ongoing tension between culturalisation and commodification is, for a number of reasons, unsurprising. On the one hand, football as a rich cultural object is ripe for colonisation by the market because it commands durable symbols, meanings and sources of identity that can be tapped as a rich source of profit. On the other hand, as an object of support and/or practice steeped in cultural meaning and identity-forming significance, football is also highly resistant to the processes involved in commodification. Moreover, this tension brings us back to du Gay's (2002) observation that the intersection of culture and economy is largely a result of ongoing 'techniques of economic management'. Therefore, to what extent might Supporters Direct represent an important strand in a range of 'techniques' aimed at the 'economic management' of football supporters in the context of the increasing commodification of the game?

\section{Summary}

3.11 Supporters Direct holds out the attraction of developing the commodification of football along the potentially more democratic path offered by mutualisation: serving as a progressive force in rejecting both the 'golden era' of paternalist control and the rampant commercialism pervasive in modern football. In this respect, Supporters Direct could provide the means for a re-articulation between culture and economy in terms more favourable to football supporters. However, and driven by the wider context of commodification outlined above, the circumscription of Supporters Direct within a social inclusion agenda places fundamental limits on its capacity to mount a decisive challenge to the increasing commercialisation and commodification of football. It is the tension between these two possibilities that is not explored in current research on the development and meaning of Supporters Direct. In section three, we address the implications of this tension for the development of the supporters' trust movement and for their relationship with grassroots football support.

\section{Section Three}

\section{Supporters' Trusts: Vehicles for Mutual Ownership or Technique for Supporter Control?}

4.1 The benefits argued to flow from supporters' trusts seem undeniable. They hold out the prospect of football supporters taking an active part in the running of their clubs and, eventually, taking over their full ownership and control. Michie makes the point that 'moving towards some sort of mutual structure' would allow supporters' feelings of moral ownership of clubs - something reflective of the emotional (as well as financial) investment supporters make - to be transformed into reality' (1999: 15). Mutualisation does, of course, hold the potential to promote supporters into positions where they can exercise participatory democracy and to extend supporter involvement in their clubs to include some level of legal ownership of it. As we have witnessed, as a result of the activity of individual supporters' trusts, a small number of lower league clubs are now owned outright by their supporters. This type of development marks significant progress for supporters from their traditional status as, at best, 'consulted customer' and, at worst, that of passive and manipulated 'consumer'. In this sense supporters' trusts may aspire towards a more allembracing citizenship that allows the dreams and aspirations of fans to prosper.

4.2 However, is it this same premise that makes supporters' trusts such powerful 'techniques' for colonising supporter relations along a more commodified pathway? In particular, a supporter's sense of moral ownership of their club can become blurred by the diktats of economic ownership, converting the traditional feelings of emotional solidarity between supporters in their attachment to the club into more instrumental and quantifiable forms of attachment. Mutualisation, it ought to be stressed, even in the most favourable conditions - for example, where there is a statutory commitment to governance by mutuality - creates only the potential for participatory democracy, it does not simply arise out of the establishment of mutuality. [17] Mutuality could just as well revert to the more passive and, on many occasions, manipulative relations of producer-consumer inherent to profit shareholder forms of governance. After all, mutuals must still derive profits so they can invest in the organisation in order to keep up with the competition, to develop and to survive. Democratically elected boards must deliver and execute business plans based on an economic 
rationality, which may well come into tension with parallel social objectives (Reid, 2003). Such is the capitalist context within which mutual forms of governance must be located. The point here is that such pressures provide fertile ground for the democratic potential inherent in mutualisation to become compromised and even negated, as it becomes a technique towards commodification. As supporters are drawn deeper into football as a business within an industrial complex, there is clearly the potential that they will be inclined to view performance with an eye to the consequences for the latest club audit.

4.3 Indeed, it can be argued in this respect that Supporters Direct - in their role as mentor to football trusts - provides the impulse to deepen and extend relations of commodification between supporter and club.

Research for example indicates that the majority of supporters' trusts make cash donations to their football clubs, with almost half of the trust movement viewing such activities as either an 'important' or 'very important' part of a trust's activities. (Perhaps tellingly, almost 80 per cent of football clubs surveyed believed supporters' trusts should fundraise for their clubs - FGRC, 2005: 62-63). This contradicts the view propounded by Supporters Direct that there is a major difference in this respect between the roles of the traditional supporter's clubs and supporters' trusts - the latter more typically associated with the concept of donating to the club cause. ${ }^{[18]}$ These donations take the form of supporters' trust membership fees, individual cash donations, fundraising at local community events, and applications for community grants and awards (FGRC, 2005: 58-59). Through their supervision of the supporters' trust movement, Supporters Direct have, since 2000, brought £10 million of extra investment (Supporters Direct, 2006a) into British football from a variety of sources. The issue of community grants provides a particularly good example of the use made of trusts by football clubs. Most football clubs 'as (technically) profit making entities' (FGRC, 2003b: 38) cannot bid for the variety of public funds that are available to local community organisations, such as the Community Fund, Neighbourhood Renewal Fund, the Community Chest, or the European Social Fund. Working in partnership with a supporters' trust, though, enables clubs to tap into these sources of revenue, as supporters' trusts are not-for-profit organisations. The football industry's auditors, Deloitte and Touche, underline the importance of these revenue sources as an opportunity for value creation opening up to football clubs: 'There is an increasing amount of supporter involvement in the ownership and operation of clubs...Primarily, this has been driven by the supporters' trust movement...A strong relationship between club and community is also good for business' (Supporters Direct, 2001: 9). The case is being made in this statement that, while there are community benefits to this engagement strategy such as greater youth involvement in football and the elimination of racists from football grounds supporters' trusts can access 'revenue streams' that are inaccessible to PLCs by pioneering such campaigns (Hamil, 2003: 38). This is a thought echoed by Supporters Direct Chief Executive, Philip French: 'Clubs are beginning to understand that supporters representation and strong trusts are not a threat but a much valued necessity improving the operation and running of clubs' (Supporters Direct, 2005b: 5). ${ }^{[19]}$

4.4 There is, then, an apparent contradiction concerning the supporters' trust movement: its 'levelling' ideology being counterbalanced by a willingness to be utilised for commercial purposes by the club hierarchies they seek to replace. This contradiction, we believe, has implications for the development of the movement. Evidence suggests that there is an ambiguous attitude amongst grassroots supporters regarding how progressive the trust movement is and how much it can achieve.

\section{Football Supporters and Supporters' Trusts}

4.5 Certain indicators suggest that ordinary supporters remain favourable toward the principle of supporters' trusts becoming involved in the running of football clubs. Many talk of their presence as being a long overdue intervention which can bring about a 'a measure of democracy to football clubs' (One Touch Football, 2004a); that they are 'a much better way of running [clubs]' (Urban 75 Forums, 2005); and are an obvious starting point for supporters looking to constructively improve their lot, rather than to simply complain about being exploited (One Touch Football, 2005; Big Football Forum, 2004).

4.6 There are signs beginning to emerge, though, that the trust movement, amongst some sections of football supporters at least, faces a questioning of its legitimacy. This relates to the ability of trusts to put into action their objective to effectively redress the balance of power at football clubs, and thereby remain outside the orbit of influence of club hierarchies and their financial agendas.

4.7 It is, perhaps, an unchallengeable statement to make that supporters' trusts only become central stakeholders in a club in a situation of financial crisis, where a club is forced to turn to hitherto unconsidered sources of investment. For example, full supporter ownership and control has occurred at twelve clubs: four of these in English Football League Division Two and Three; eight involved in semiprofessional leagues (Supporters Direct, 2006b). As David Conn (2000: 31) asserts in relation to fan control of the bigger clubs in particular, such "heady thoughts of "rolling back the PLC"... have melted into the realization that mutualising the big clubs is currently impossible'. This failure of the trust movement to make significant inroads into the governance of football clubs has been recognised by football supporters. It 
is clear that some now doubt the possibility of reforming football from a situation where 'fat cats in boardrooms count notes' (Urban 75 Forums, 2005), to a point when clubs are run successfully along democratic lines. Indeed, figures relating to trust ownership of shares demonstrates that only in one of the 34 clubs in football's top flight in England (The Premiership and The Championship), and 13 of the 48 lower league clubs (League One and League Two) do trusts hold 'significant' amounts of shares in their clubs (FGRC, 2005: 52-55). ${ }^{[20]}$ There is a perceptible growth in the feeling that trusts continue to be 'locked out' and 'wield limited influence' in club decision making processes (One Touch Football, 2004a), something which appears to be generating a degree of apathy regarding the value of trust membership (Big Football Forum, 2005). Only in the lower divisions of football (and here in only a fraction of clubs) is there anything like a substantial overlap between trust membership and club support (FGRC, 2005: 52-55).

4.8 This lack of influence in club affairs seems, in some instances at least, to have persuaded trusts to pursue the controversial tactic of allying with individuals holding large amounts of club shares (or seeking to gain large amounts). This has led to suspicions developing between trusts and other supporters. For example, The Owls Trust (Sheffield Wednesday supporters' trust) became entangled in the takeover bid for Sheffield Wednesday by (present Leeds United chairman) Ken Bates in 2004. The Owls Trust were accused of coming to an arrangement with Bates in his bid for ownership in return for increasing their own influence in the club. The Owls Trust received strong condemnation from many Sheffield Wednesday supporters for their actions (One Touch Football, 2004b). The Celtic Trust was also criticized for its use of the shares of Simple Minds singer and Celtic supporter, Jim Kerr, in order to force motions at a Celtic AGM. Kerr had previously been part of a proposed consortium seeking to take control of Celtic FC in 1998, and there was speculation amongst Celtic supporters that the Celtic Trust was being used as 'a vehicle for increasing the power and influence of a number of prominent individuals who currently sit outside the boardroom' (E-Tims, 2004). At Peterborough United, The Posh Trust were allotted a place on the board, and worked very closely with, the regime of Barry Fry when his consortium took over ownership of that club in 2003 (Supporters Direct, 2004a: 16), despite Fry's obvious unpopularity amongst the club's supporters (Peterborough Today, 2006).

4.9 Such examples could be argued to be atypical of the response of supporters' trusts to the problems they face in wielding influence within football clubs. They could also be argued, however, to be the logical actions of organizations working within the parameters of a government agency, Supporters Direct, whose fundamental role is to manage if not extend the commodification of football. Indeed, the actions of these named trusts may be considered to be a harbinger for the future direction of the trust movement. It seems clear from literature and pronouncements made by Supporters Direct in the past year that they are in the process of encouraging supporter's trusts to cast off their I\&PS status and embrace the structure and rules of "Community Interest Companies (CICs). CICs can be described as a "half-way-house" between a traditional mutual (such as an I\&PS) and a private limited company. CICs (organizations being given this status by proving that they add "social value" to communities) encourage private investment in return for dividend payments on shares bought and/or interest payments on loans made (CIC, 2006). CICs can be used as an asset base for attracting loans (debt), making them an attractive proposition for business investors. In the words of Supporters Direct, the philosophy of the $\mathrm{CIC}$ 'attempts to reconcile the aims underpinning a social enterprise - community benefits, community need, environmental concerns - with the needs of the investors who have the capital needed to enable these social enterprises to grow and flourish' (Supporters Direct, 2005c: 6). In relation to supporters' trusts, this model of organization is increasingly being advocated due to the experience of trusts taking control (or having the opportunity to take control) of failing clubs, but who are not then able to keep their ambitions afloat financially (Supporters Direct, 2006c: 2). Despite the reassuring words of Supporters Direct that this would be a democratic alternative to the use of private capital, such a move toward the $\mathrm{CIC}$ model - a joint venture between supporters and commercial entities - would undoubtedly provide the potential for problems over company decision making regarding community and investment objectives, and compromise the original ideals which have won the trust movement favour in many quarters.

\section{Summary}

4.10 As we have seen, whilst it is true to say that the ideology of the supporters' trust movement has struck a chord amongst many British football club supporters, there are signs beginning to emerge that the trust movement faces a questioning of its ability to effect change amongst football clubs (and, in some instances, their methods of attempting to gain influence). Certain evidence points to an element of suspicion amongst some football club supporters toward supporters' trusts, and it is clear that this suspicion is fuelled by a belief that those leading the trust movement are tainted by economic rationalism. This, we believe, relates to the social and political context that trusts operate within and, more particularly, to their connection to Supporters Direct. These tendencies appear to point in the direction of resistance to the message and practices of trusts, which could provide an obstacle to the supporters' trust movement being able to significantly deepen its influence amongst football club supporters in the future. 


\section{Conclusion}

5.1 In this paper the genesis of Supporters Direct has been located as part of the New Labour Government's attempt to tackle the increased commercialisation of British football that has occurred since the early 1990s. It has been argued that football has been utilised by New Labour as an instrument for the fulfilment of their objective of creating a socially inclusive, market-based society based on the extension of commodified social relations, and that commodification as a process is implicit both to government policy in relation to football, and to the development of Supporters Direct in particular. The overarching argument here has been that Supporters Direct cannot simply be posited as a force for progress, but must instead be treated as both a response to, and the project of, wider processes of commodification sweeping through society. Accordingly, we recognised the tensions and ambiguities faced by the supporters' trust movement and argued that, though they may hold out the possibility for the re-colonisation of football clubs in the interests of football supporters as a whole, they are subject to the influence of commodification due to their relationship to Supporters Direct, a creation of government policy to enhance social inclusion.

5.2 With respect to future research, it is the case that the vast majority of British football fandom remains outside of the supporters' trust movement (FGRC, 2005: 52-56). Fragmentary evidence provided in this paper suggests that the trust movement faces a questioning of its legitimacy by ordinary supporters. We believe, therefore, that more extensive research attempting to gauge supporters' reaction (at all divisional levels of football) to the supporters' trust movement is long overdue. A meaningful discourse with British football fandom could provide valuable insight into the validity of some of the central assertions made in this paper regarding, what we have argued to be, the ongoing commodification of football in Britain and the role played in this process by Supporters Direct and the supporters' trust movement.

\section{Notes}

1 Though both Rugby League and Rugby Union clubs have established Trusts with the help of Supporters Direct. By July 2006, 4 rugby union clubs and six rugby league clubs had established supporters' trusts. See Supporters Direct (2006c), p.31.

2 See, for example, J. Michie, (1999); S. Hamil, J. Mitchie and C. Oughton (eds) (1999); S.Hamil, J. Michie, C. Oughton and S. Warby (Eds) (2000).

${ }^{3}$ Football Task Force, (London Stationary Office, 1998); Football Task Force, (London Stationary Office, 1998); Football Task Force, (London Stationary Office, 1999a); Football Task Force, (London Stationary Office, 1999b). For an overview of the Football Task Force see R. Faulkner (2000), pp36-44.

${ }^{4}$ S. Hamil (1999) p.24-26. Between the 1990/91 season and the 1994/95 season attendances rose by 15 per cent for English clubs.

${ }^{5}$ D. Conn (1998), p.49. The new Premier League struck a five-year deal with BskyB worth $£ 304$ million.

6 ibid. pp.45-46. Though the FL did try to pacify the elite clubs by agreeing to concessions on the distribution of TV money in their favour in both 1985 and 1988.

${ }^{7}$ Quote taken from J. Reid (2001), p.35. By season 1999/2000 the twenty Premiership clubs generated a total income of $£ 772 \mathrm{~m}$, over twice the income total for the seventy two Football League clubs. (See J. Reid, 2001, pp.12-13).

8 ibid p.16. Reid points out that the price of a ground ticket at Anfield in 1987 was £3. By 2001 this had risen to between $£ 19-£ 27$. The price of the ticket if it had kept pace with inflation would have been just $£ 6$ in 2001 . At the time of writing the ground entrance fee at Liverpool stands at £26-£30. See Liverpool FC (2006). Reid suggests that the middle classes have increased their presence at football matches at the expense of working classes (p.16)

${ }^{9} 9$ A Football Task Force survey estimated that in 1988 average season ticket prices across all four English divisions was £73. If season ticket prices had kept pace with inflation, by 2004 the average English Football League season ticket price would have been $£ 123$, instead of the average of $£ 325$ it was found to be in a follow up study that year (Supporters Direct, 2004b, p.10). Hudson (2001), however, makes the case that the social exclusion from football match attendance of sections of the population is not just a late twentieth century phenomenon, but was also experienced in the so called "golden age" of football's development and growth to maturity. 
10 Tischler (1981) more especially makes the case that football club directors were in a prime position to exploit their own clubs by providing certain business services, such as food, refreshments or building services in the guise of vendors to the club. See also Hudson (2001).

${ }^{11}$ Burnham, though, makes the point that a fundamental mistake was made by the football authorities in the game's early period by failing to turn clubs into mutual trusts. This later laid the basis for the rampant commercialisation of the game in a later era. See Burnham, (2003) p.15.

12 A phrase taken from the 1991 Football League document One Game, One Team, One Voice, which called for, as a means of counteracting the commercial instincts of the elite clubs, the unification of the Football League and Football Association as a means to preserve the unity of the English games 92 club structure and a commitment to the historic sharing principle regarding the games revenues. See $\mathrm{D}$. Conn, (1998), pp140-41.

13 In particular, the Task Force report and recommendations on tackling the problem of racism at football grounds saw the passing of a law in 1999 criminalizing racist chanting inside football stadia. See S. Hamil (2000), p38.

14 Industrial Provident Societies (2006)

${ }^{15}$ A Supporters' Trust could, however, adopt a constitution where the voting rights that go with share ownership could be transferred by proxy to be used by the Trust board but whereby dividends accruing from shares owned would pass to the share owner.

16 Of course the link between football and policies of social inclusion stretch beyond the present government. Social exclusion has been closely associated with football and has been a central focus of football research since the 1970s. In particular, football hooliganism, which initially preoccupied football research, was initially portrayed as the reaction of 'authentic working class fans' against the threat of exclusion posed by the commercialisation and gentrification of football support in the 1970s. By the 1980s this view was overtaken by one which situated hooliganism as an exclusionary process in itself, fuelled by a mixture of 'the rights of passage to adulthood' and 'tribalism'. See Wagg (2004).

17 This is a point made by Dominic Malcolm (2000), p109. Malcolm points to the danger of supporters' groups becoming 'dominated by an active minority' unrepresentative, demographically speaking, of the wider club support. See FGRC (2003a) where the social complexion of the vast majority of seven West Midland supporters' trust boards were found to be overwhelmingly white, middle-aged males. See also M. Jackson and P. Maltby (2003), p.6.

18 In particular, this donor aspect to supporter's trusts is rebuffed by Supporters Direct's Deputy Chief Executive, Dave Boyle: 'Gone were the days when would simply hand over money. That is not their role'. Speaking at Peterborough Supporters' Trust AGM, 11 September 2006. See Posh Supporters' Trust (2006)

${ }^{19}$ Closer analysis reveals that Supporters Direct is highly instrumental in its approach to supporters outside the trust movement too, positioning them in market relations: supporters display 'a degree of customer loyalty that is unprecedented in other lines of business'; 'football fans contribute to the "output" or "value"' generated by clubs over and above the money they spend on tickets; "packed and atmospheric stadiums...make the matches more attractive to broadcasters and increases their value'. (Hamil, 2003: 25). Indeed, the relationship between supporters, clubs and the community is highly commodified in the language deployed by Supporters Direct. The following statement highlights this point to good effect: 'Most supporters' trusts include among their objectives strengthening links between the club, supporters and the community, fundraising for the club, attaining a shareholding and promoting youth involvement, equal opportunities and anti-racism initiatives. All of these activities can help widen the revenue base of clubs and/or increase clubs share capital' (Hamil, 2003: 36).

${ }^{20}$ As noted in the FGRC report, 'significant' share ownership refers to anything over 1 per cent of share capital in a listed PLC; anything over 5 per cent of share capital in private limited companies or PLCs not listed. The figures published in the report for share ownership of trusts also includes shares not owned by the trust but are proxied to them for voting purposes. The number of clubs where trsusts 'own' significant amounts of shares, then, could be inflated.

\section{References}

ARNAUT, J.L. (2006) Independent European Sports Review, European Union Report: UK Presidency of the 
BIG FOOTBALL FORUM (2004) General Football Forum, 'Football Fans are Idiots', 25 October $<$ http://www.big-football-forum.co.uk/forum/> (site accessed 18 October 2006).

BIG FOOTBALL FORUM (2005) General Football Forum, 'Supporters Clubs/Trusts', 13 January $<$ http://www.big-football-forum.co.uk/forum/> (site accessed 18 October 2006).

BOYLE, D. (2003) 'Dispatches from the Front Line of Supporter Democracy', in Jackson, M. and Maltby, P. (eds) Trust in Football, pamphlet by The Institute for Public Policy Research, London, June.

BRICK, C. (2001) 'Anti-consumption or New Consumption? Commodification, Identity and New Football', in J. Horne Leisure Cultures, Consumption and Commodification, Brighton, LSA.

BROWN, A. (2002) 'A task of two halves', <http://www.democraticsocialist.org.uk/ds74ftf.htm> (site accessed 16 June 2006).

BROWN, A. Crabbe, T. Mellor, G. Blackshaw, T and Stone, C. (2006) Football and Communities: Final Report. Manchester, Football Foundation, <http://www.footballfoundation.org.uk/news-andmedia/publications/football-and-its-communities-final-report> (accessed 20 August 2006).

BURNHAM, A., (2003) 'Regulation, Redistribution and Mutualisation: A Red-In-Tooth-and-Claw Cure For Football's Ills', in Matt Jackson and Paul Maltby (Eds) Trust in Football, London, pamphlet by The Institute for Public Policy Research, June.

CIC (2006) Community Interest Companies <http://unw.cicregulator.gov.uk> (site accessed 18 October 2006).

CONN, D. (2000) 'Trust in Football', in S. Hamil, J. Michie, C. Oughton and S.Warby (Eds), The Changing Face of the Football Business, Soccer and Society, volume 1, number 3, autumn.

CONN, D. (1998) 'The Football Business: Fair Game in the '90s?', Edinburgh, Mainstream

DU GAY, P. and Pryke, M., (2002) (eds) Culture and Economy: Cultural Analysis and Commercial Life , London, Sage.

E-TIMS, (2004) 'It's a matter of Trust' 17 July. <http://www.etims.net> (site accessed 7 February 2006)

FAULKNER, R. (2000) 'The Legacy of the Football Task Force' in S. Hamil, J. Michie, C. Oughton and S.Warby (Eds), The Changing Face of the Football Business, Soccer and Society, volume 1, number 3, autumn (ch6).

FGRC (Football Governance Research Centre) (2003a), 'Building Sustainable Supporters' Trusts in the West Midlands'. <http://www.football-research.org/interimr/interimreport-wholetrust.htm\#top> (site accessed 28 August 2006)

FGRC (Football Governance Research Centre) (2003b), The State of the Game: The Corporate Governance of Football Clubs, Research Paper 4, Birckbeck, University of London.

FGRC (Football Governance Research Centre) (2005), The State of the Game: The Corporate Governance of Football Clubs, Research Paper 3, Birckbeck, University of London.

FOOTBALL ASSOCIATION. (1991) The Blueprint for the Future of Football , London, Football Association publication.

HAMIL, S., Mitchie, J., and Oughton, C. (eds), (1999) 'A Whole New Ball Game: Why Football Needs a Regulator', in The Business of Football : A Game of Two Halves, Edinburgh, Mainstream.

HAMIL, S., Michie, J., Oughton., C and Warby., S. (eds), 2000 'Recent Developments in Football Ownership', The Changing Face of the Football Business, Soccer and Society, volume 1, number 3, autumn.

HAMIL, S. (2003) The Third Annual State of the Game Survey of Governance at Professional Football Clubs, 2004, Football Governance Research Centre, Birkbeck, University of London, November.

HOLT, R. (1989) Sport and the British, Oxford.

HORNE, J. (2006) Sport in Consumer Culture, London, Palgrave Macmillan. 
HUDSON, J. (2001) 'Critically Examining the Commercialisation of English Football: A Case for Government Intervention?', Sociology of Sport Online, vol.4, no.1.

<http://physed.otago.ac.nz/sosol/v4i1/v4i1hud.htm> (site accessed 3 Septemeber 2006).

INDUSTRIAL PROVIDENT SOCIETIES (2006) http://www.vikingsc.f9.co.uk/About_IPS.htm (site accessed 4 March 2006).

JACKSON, M. and Maltby, P. (2003) Trust in Football, pamphlet by The Institute for Public Policy Research, London, June.

JAQUISS, K. (2000) 'Mutualism Rules: The Community in Football' in, S. Hamil, J. Michie, C. Oughton., and S. Warby, (eds), The Changing Face of the Football Business, Soccer and Society, volume 3, number 1 , autumn.

LEVITAS, R. (1998) The Inclusive Society? Social Exclusion and New Labour, London, Macmillan.

LIVERPOOL FC (2006) <http://www.liverpoolfc.tv/tickets/howtoapply.htm\#10> (site accessed 3 June 2006)

MALCOLM, D. (2000) 'The Changing Face of the Football Business', Soccer and Society, volume 1, number 3 , autumn.

MASON, A. (1980) Association Football and English Society, 1863-1915, Brighton, Harvester Press.

MICHIE, J. (1999) New Mutualism A Golden Goal? Uniting supporters and their clubs, London, Cooperative Party, London, Trafford Press Ltd.

ONE TOUCH FOOTBALL FORUM, (2004a) 'Franchise: A Matter of Trust', 27 October,

<http://www.onetouchfootball.com> (site accessed 1 June 2006)

ONE TOUCH FOOTBALL Forum, (2004b) 'Black Balloons', 23 April,

<http://www.onetouchfootball.com>(site accessed 1 June 2006).

ONE TOUCH FOOTBALL FORUM, (2005) 'The Self Disgust of the Modern Football Fan', 16 August, <http://www.onetouchfootball.com>(site accessed October 19 2006).

PETERBOROUGH TODAY (2006) 'Your Comments' 19 September, <http://www.peterboroughtoday.co.uk> POSH SUPPORTERS' TRUST (2006) <http://www.theposhtrust.com/minutes/agm2006.htm>(site accessed 23 October 2006).

REID, G. (2003) 'Charitable Trusts: Municipal Leisure's “Third Way”?, Managing Leisure, vol.8, pp.171-83.

REID, J. (2001) Reclaim the Game; Ten Seasons of the Premier League Swindle, London, Biddles Ltd, Sixth Edition.

RUSSELL, D. (1996) Football and the English, Preston, Carnegie.

SUPPORTERS DIRECT. (2001) News/etter, December. < http://www.supporters-

direct.org/englandwales/library.htm>

SUPPORTERS DIRECT. (2004a) Newsletter, January. <http://www.supporters-

direct.org/englandwales/library.htm>

SUPPORTERS DIRECT. (2004b) Newsletter, December. <http://www.supportersdirect.org/englandwales/library.htm>

SUPPORTERS DIRECT. (2005a) Newsletter, March. <http://www.supportersdirect.org/englandwales/library.htm>

SUPPORTERS DIRECT. (2005b) Newsletter, June. <http://www.supportersdirect.org/englandwales/library.htm>

SUPPORTERS DIRECT. (2005c) Newsletter, September. <http://www.supportersdirect.org/englandwales/library.htm>

SUPPORTERS DIRECT. (2006a) News/etter, March. <http://www.supportersdirect.org/englandwales/library.htm> 
SUPPORTERS DIRECT. (2006b) Newsletter, July. <http://www.supportersdirect.org/englandwales/library.htm>

SUPPORTERS DIRECT. (2006c) Newsletter, September. <http://www.supportersdirect.org/englandwales/library.htm>

TAYLOR, R. (1990) Inquiry by Right Honourable Lord Justice The Hillsborough Stadium Disaster: Final Report, London, HMSO.

THE FOOTBALL TASK FORCE. (1998) Eliminating Racism From Football, London Stationary Office.

THE FOOTBALL TASK FORCE (1998) Improving Facilities for Disabled Supporters, London Stationary Office.

THE FOOTBALL TASK FORCE. (1999a) Investing in the Community, London Stationary Office.

THE FOOTBALL TASK FORCE. (1999b) Commercial Issues, London Stationary Office.

TISCHLER, S. (1981) Footballers and Businessmen: The Origins of Professional Soccer in England, New York, Holmes and Meier Publishers.

URBAN 75 FORUMS (2005) Football/Sport Forum 'Has There Ever Been a Co-Op Run League Club?', 30 August. <http://www.urban75.net> (site accessed 20 October 2006).

WARDE, A. (2002) Production, consumption and 'cultural economy', in P. du Gay and M. Pryke, (ed) Culture and Economy: cultural analysis and commercial life. London, Sage.

WILLIAMS, R. (1976) Keywords: A Vocabulary of Culture and Society, Glasgow, Fontana.

WAGG, S. (1998) Sack the Board, Sack the Board, Sack the Board, in U. Merkel, G. Lines, and I. McDonald, Production and Consumption of Sport Cultures: Leisure, Culture and Commerce, London, LSA Publication No 62. 